Article

\title{
Picking Up the Pieces-Harmonising and Collating Seabed Substrate Data for European Maritime Areas
}

\author{
Anu Marii Kaskela ${ }^{1}$, Aarno Tapio Kotilainen ${ }^{1, *}$, Ulla Alanen ${ }^{1}$, Rhys Cooper ${ }^{2}$, Sophie Green ${ }^{2}$, \\ Janine Guinan ${ }^{3}$, Sytze van Heteren ${ }^{4}$, Susanna Kihlman ${ }^{1}$, Vera Van Lancker ${ }^{5}$ (D), \\ Alan Stevenson ${ }^{2}$ and the EMODnet Geology Partners ${ }^{\dagger}$ \\ 1 Geological Survey of Finland GTK, 02151 Espoo, Finland; anu.kaskela@gtk.fi (A.M.K.); \\ ulla.alanen@gtk.fi (U.A.); susanna.kihlman@gtk.fi (S.K.) \\ 2 British Geological Survey, Edinburgh, Currie EH14 4BA, UK; rcooper@bgs.ac.uk (R.C.); \\ soph@bgs.ac.uk (S.G.); agst@bgs.ac.uk (A.S.) \\ 3 Geological Survey Ireland, DO4 K7X4 Dublin, Ireland; janine.guinan@gsi.ie \\ 4 Geological Survey of the Netherlands, PO Box 80015, NL-3508 TA Utrecht, The Netherlands; \\ sytze.vanheteren@tno.nl \\ 5 Royal Belgian Institute of Natural Sciences, 1000 Brussels, Belgium; vvanlancker@naturalsciences.be \\ * Correspondence: aarno.kotilainen@gtk.fi; Tel.: +358-29-503-0000 \\ + The EMODnet Geology Partners are provided in the Acknowledgments.
}

Received: 31 December 2018; Accepted: 6 February 2019; Published: 13 February 2019

\begin{abstract}
The poor access to data on the marine environment is a handicap to government decision-making, a barrier to scientific understanding and an obstacle to economic growth. In this light, the European Commission initiated the European Marine Observation and Data Network (EMODnet) in 2009 to assemble and disseminate hitherto dispersed marine data. In the ten years since then, EMODnet has become a key producer of publicly available, harmonised datasets covering broad areas. This paper describes the methodologies applied in EMODnet Geology project to produce fully populated GIS layers of seabed substrate distribution for the European marine areas. We describe steps involved in translating national seabed substrate data, conforming to various standards, into a uniform EMODnet substrate classification scheme (i.e., the Folk sediment classification). Rock and boulders form an additional substrate class. Seabed substrate data products at scales of 1:250,000 and 1:1 million, compiled using descriptions and analyses of seabed samples as well as interpreted acoustic images, cover about $20 \%$ and $65 \%$ of the European maritime areas, respectively. A simple confidence assessment, based on sample and acoustic coverage, is helpful in identifying data gaps. The harmonised seabed substrate maps are particularly useful in supraregional, transnational and pan-European marine spatial planning.
\end{abstract}

Keywords: marine geology; seafloor mapping; seabed substrate; harmonisation; confidence; spatial scale; data gaps; European seas; EMODnet

\section{Introduction}

Rapid population growth and increased anthropogenic activities in coastal and marine areas have affected the marine environment on a worldwide scale [1,2]. Anthropogenic uses of marine areas are ever expanding [3] and pose great challenges to successful maritime spatial planning. They exacerbate impacts of climate change on our ocean ecosystems [4]. Efficient and sustainable management of large sea areas requires multidisciplinary information on the marine environment, though it is commonly hampered by a lack of data, or comprehensive information on the sea areas [5,6]. In addition, there is a need to improve on data exchange channels and to resolve incompatibilities between flawed datasets that still challenge effective marine spatial planning [6]. These issues were highlighted in several 
national and international policy guidance documents, including the EU Marine Strategy Framework Directive (MSFD) [7] and EU Maritime Spatial Planning Directive (Directive 2014/89/EU) [8].

This paper discusses steps taken during the past decade towards integrated knowledge on the European seafloor, as part of the European Marine Observation and Data Network (EMODnet). The EMODnet network was initiated by the European Commission in response to the EU Green Paper on Future Maritime Policy (European Commission 2006), which identified key data gaps. It now involves more than 160 organisations assembling marine data, products and metadata in various consortia. A web portal unlocks fragmented marine data resources, previously hidden from international sight, making important datasets available for public and private users. It facilitates investment in sustainable coastal and offshore activities through better access to quality-assured, standardised and harmonised marine data, which are interoperable and free of restrictions on use.

The EMODnet data infrastructure is being developed through a stepwise approach in three major phases. The first phase (2009-2012; ur-EMODnet) developed a prototype with limited selection of sea areas/coverage at low resolution. The second phase (2013-2016) provided improved resolution and coverage, while the present third phase (2017-2019) works towards providing a seamless multi-resolution digital map of the entire seabed of European waters at the highest possible resolution.

The EMODnet initiative includes several specific themes. One of these, EMODnet Geology, is tasked with providing marine geological data on European marine areas to individuals and organisations (http://www.emodnet-geology.eu/). The EMODnet Geology consortium consists mainly of the marine departments of the geological surveys of Europe (through the Association of European Geological Surveys-EuroGeoSurveys), and includes additional national organisations with responsibility for coastal and marine geological mapping in their respective countries. This European wide partnership allows access to a vast amount of marine geological data, together with metadata and other knowledge on how original datasets (e.g., seabed substrate map) have been generated. In the case of seabed substrate maps, information on used remote sensing (e.g., side-scan sonar, single and multibeam echo sounders, seismics) and sampling methods (e.g., grab sampling, coring), as well as on data interpretation or modelling methodologies, is available too.

Given that much of our seas and oceans remain unchartered, there is an ongoing requirement for maps and data that accurately represent the properties of the seabed for the benefits of research, resource management, setting conservation objectives and marine spatial planning [9,10]. EMODnet Geology addresses the deficit of pan-European substrate information. Seabed substrate maps on different scales are some of the key deliverables of the project.

This paper describes methodologies used to produce a fully populated Geographic Information System (GIS) layer of seabed substrates for the European maritime areas. Following an evaluation of the different sediment classification schemes used by each contributor, we describe the processes involved in translating national seabed substrate data into the EMODnet substrate classification scheme, the Folk sediment classification. During the first phase of EMODnet, seabed substrate information from northern sea areas was compiled at a 1:1,000,000 (1 M) scale [11]. The second phase produced a 1:250,000 (250 k) map for all European seas. In addition, for the second phase, the low resolution (1 M) dataset of the first phase was updated with data from Southern European sea areas. The harmonised data products visualise the European seafloor showing the similarities and differences of the sea basin substrate distribution/characteristics. Additionally, the data displays data gaps and can be used to guide future surveys.

\section{Materials and Methods}

Our compilation of geological seabed data covers the European sea areas including: Baltic Sea, Barents Sea, Bay of Biscay, Celtic Sea, Greater North Sea, Iberian Coast, Norwegian Sea, White Sea, the seas around Iceland and the Faroes Islands, Atlantic Ocean around the Macaronesian islands, Mediterranean Sea (within waters of EU countries), and Black Sea (Figure 1). 


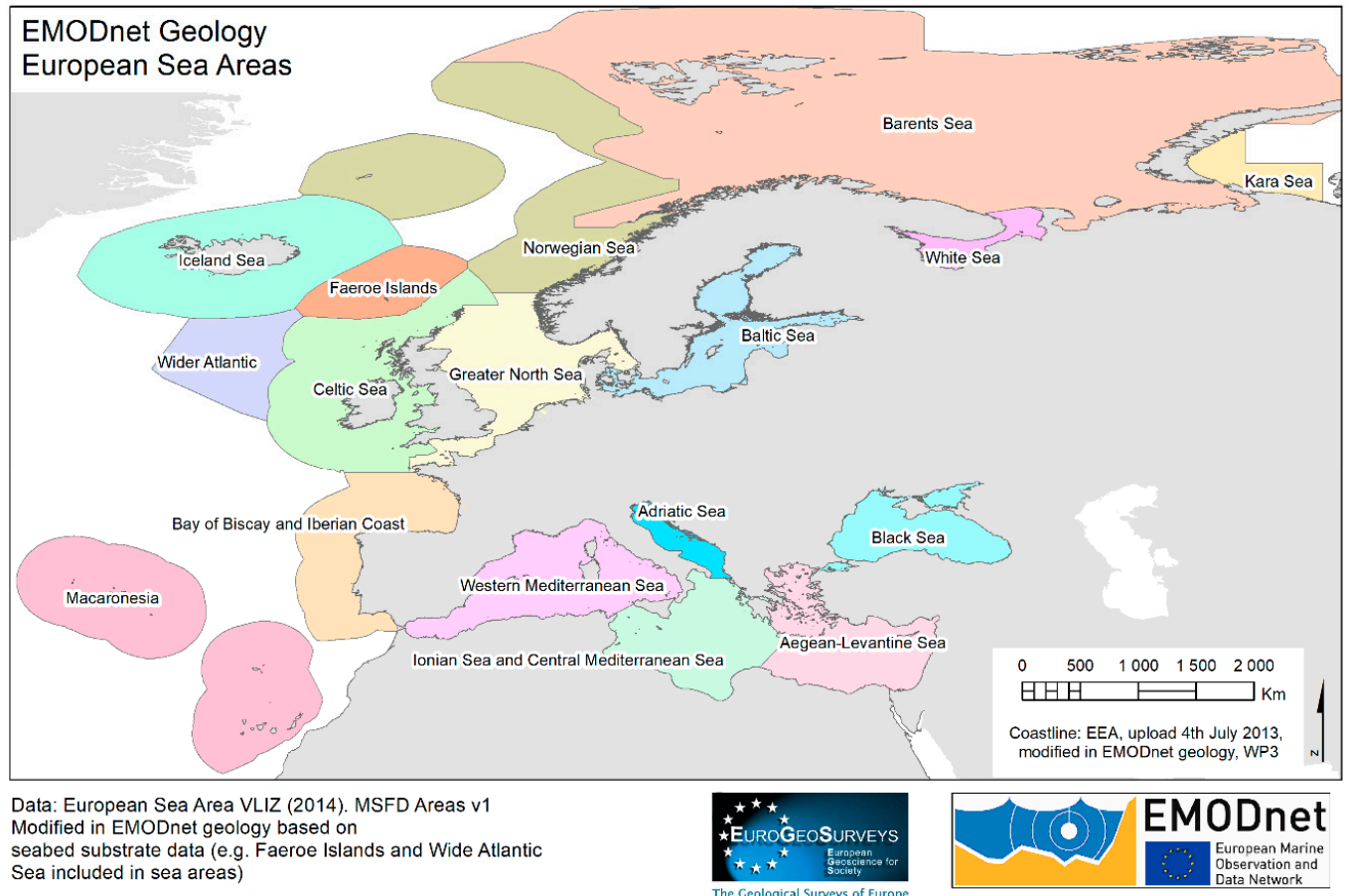

Figure 1. The European sea regions covered in the EMODnet Geology project.

The compilation of pan-European seabed substrate datasets involved the following steps: (1) Data sourcing providing an index map of available data from each of the partner organisations; (2) harmonisation; (3) generalisation; (4) compilation; and (5) confidence assessment. Project partners responsible for (parts of) different sea basins implemented steps 1 to 3 individually, following principles agreed by the project team. The partners delivered relevant data sets and metadata from their sea areas to the Geological Survey of Finland, the partner conducting data compilation and responsible for providing a harmonised data product covering the entire European marine realm. The resulting data product was distributed via the EMODnet Geology data portal, along with a confidence assessment based on data availability per survey area.

All seabed substrate datasets were provided as ESRI file geodatabases/shape files showing polygon features representing sediment classes, and all maps were provided in the WGS84 geographical coordinate system. The coastline (scale of 1:100,000) was modified from [12]. Modifications include more detailed coastline from Russia, Malta and the Canary Islands.

GIS layers of seabed substrate information were compiled on a scale of $250 \mathrm{k}$ wherever possible and $1 \mathrm{M}$ to provide the maximum data extent, as many areas lack more detailed information. To define the level of detail to be represented, it is considered that dimensions of 2-3 $\mathrm{mm}$ are the smallest which can be represented on any printed map hence the smallest cartographic unit (SCU) is $4-9 \mathrm{~mm}^{2}$ [13]. On these grounds the SCU for the $250 \mathrm{k}$ and $1 \mathrm{M}$ seabed substrate datasets are $0.25 \mathrm{~km}^{2}$ (25 hectares) and $4 \mathrm{~km}^{2}$, respectively.

\subsection{Data Sourcing}

Traditionally, marine geological survey specifications align with the survey interests, sea basin characteristics and national mapping traditions. Unsurprisingly, seabed substrates are mostly classified according to national classification schemes. The seabed substrate data used here usually originate from either manual interpretation or (semi-) automatic interpolation of seismo-acoustic data (from single-beam echo sounder lines, seismic profilers, side-scan sonars (SSS) and multibeam echo sounders (MBES)), as well as sediment-samples descriptions and analyses (e.g., [14-17]).

This information is synthesised in an index dataset delineating the available seabed substrate datasets. Along with the data and maps themselves, partners provided spatial data/polygon shapefiles 
outlining the coverage, together with an attribute table detailing background information (Table 1). Individual contributions are labelled with unique codes describing areas with a coherent and uniform scale and mapping technology (Figure 2). The index map was produced at the initial state of the project and updated during later phases.

During the first phase of the EMODnet Geology, partners gathered data on survey methods along with basic data. The data confirmed that the European seabed substrate datasets represent data acquired using a wide variety of survey methodologies (Figure 2). However, owing to the timeline, larger extent of the study area and increased number of partner countries, such information was not compiled in the second phase.

Table 1. The index shapefile/database includes an attribute table detailing basic information on each dataset.

\begin{tabular}{cr}
\hline Field & Content \\
\hline FID & Feature Identification. An internally generated identification number for each polygon. \\
\hline Shape & Polygon. Internally generated text. \\
\hline Code & Two-letter country code and three digits (numbers) that identify each data patch. \\
\hline Name & Name of the original map. \\
\hline DataHolder & Abbreviation of the organization/institute. \\
\hline Contact & E-mail address of the contact person. \\
\hline Scale & Scale of the original data/map. \\
\hline GrainSize & Original grain size classification system (e.g., Folk, Wentworth, MNCR). \\
\hline Ref. & Reference to the map. \\
\hline Comments & Comments or other information regarding the map. \\
\hline
\end{tabular}

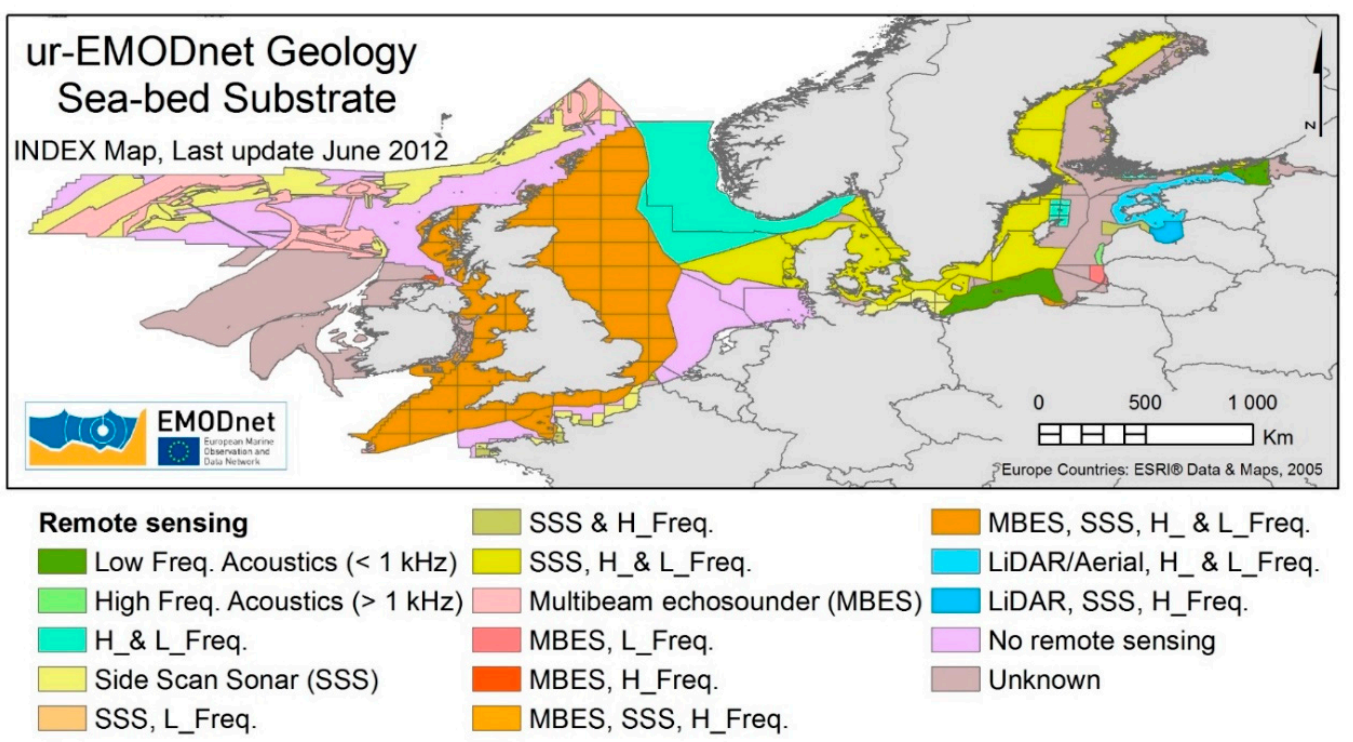

Figure 2. Different seabed survey methods and their combinations used to create national and regional substrate maps, including low-frequency acoustics (L_Freq $<1 \mathrm{kHz}$ ), high-frequency acoustics (H_Freq $>1 \mathrm{kHz}$ ), side-scan sonar (SSS), multibeam echosounder (MBES), LiDAR and no remote sensing (e.g., sample based).

\subsection{Harmonisation}

The harmonisation process included the classification of the original data into a shared, internationally-prevalent classification system for easy linkage to and use by other EMODnet lots, such as Bathymetry, Chemistry and Seabed Habitat. The Folk classification scheme [18] was chosen 
by the group because it is internationally prevalent, especially in sedimentological studies, serves the needs of habitat mappers and could be delivered by all partners, facilitating the harmonisation process across national borders. The substrate data describes the uppermost part of the seabed, from the water-bottom interface to a vertical limit of $+/-30 \mathrm{~cm}$, correlating with the approximate sample depth in the majority of cases (e.g., box corer and Van Veen grab sampler).

The partners followed a modified Folk sediment classification with three granularities of 15, 6 and 4 classes, each supplemented with an additional class of "rock and boulders" (Figure 3). A simple hierarchy enabled the straightforward union of 16 classes into 7 or 5 classes. Where possible it was recommended to use the most detailed Folk classification. If the material was classified originally using the Folk sediment triangle, no conversion was needed. If national datasets were not initially in the Folk classification, there were two options. Individual data points could be reclassified on the basis of sample analysis or description, or/and mapped units could be translated into the most likely Folk class using expert-based prediction. Experiences from previous European projects enabled reclassification in a simple and transparent way [19]. The first step in the reclassification was to study the range of surface substrate in the original categories. Ideally, this substrate type and variability was examined from the underlying surface samples and grain-size analysis. If this was not possible (e.g., because the original was interpreted on the basis of seismo-acoustic data), an expert-based prediction of the surface material was made. In an expert-based prediction, geologists interpreted data in the context of the geological and hydrodynamic environment. Then the interpreted surface sediment type was compared with the modified Folk classification system to find the best fit and reclassification was done accordingly. Extensive validation, based on ground-truthing of indirectly-mapped surface sediments, is recommended for these expert-based predictions.

Similar to the index dataset, the seabed substrate datasets included an attribute table with information on the substrates and details of reclassification where applicable (Table 2). Regarding the $250 \mathrm{k}$ data product, national security restrictions and data use policies sometimes limited data availability. The spatial boundaries of the restricted datasets are included in the seabed substrate data products as outlines marking the presence of data that are not publicly available (Code 9 restricted data).
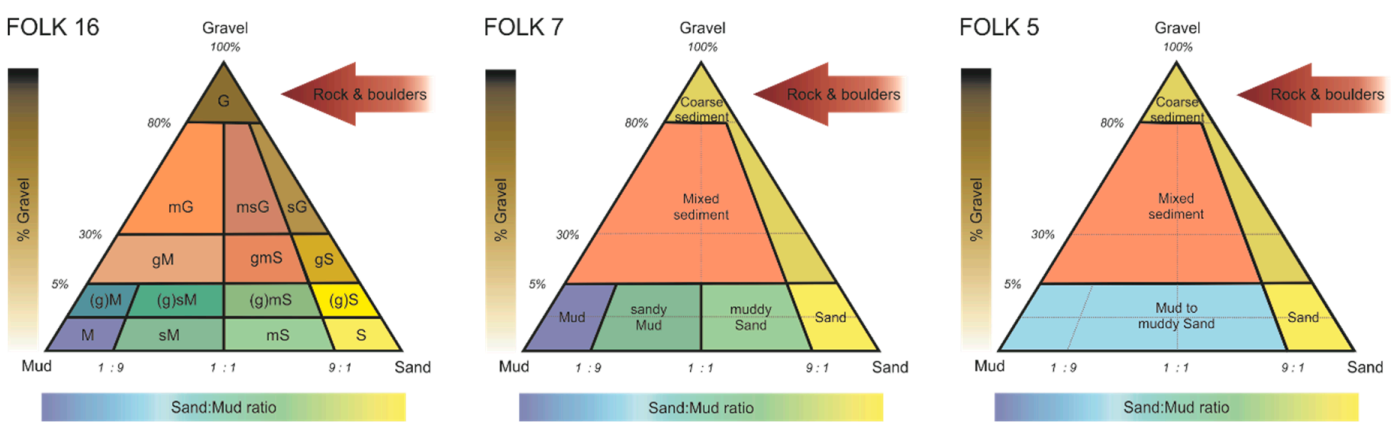

\begin{tabular}{|c|c|c|}
\hline FOLK, 16 classes & FOLK, 7 classes & FOLK, 5 classes \\
\hline Rock \& Boulders & Rock \& Boulders & Rock \& Boulders \\
\hline $\begin{array}{l}\text { Gravel - G } \\
\text { sandy Gravel - sG) } \\
\text { gravelly Sand - gS } \\
\end{array}$ & Coarse sediment & $\begin{array}{l}\text { Coarse sediment } \\
\text { (Gravel }>=80 \% \text { or (Gravel }>=5 \% \text { and Sand }>=90 \% \text { ) }\end{array}$ \\
\hline $\begin{array}{l}\text { muddy Gravel - mG } \\
\text { muddy sandy Gravel - msG } \\
\text { gravelly Mud - gM } \\
\text { gravelly muddy Sand - gmS }\end{array}$ & Mixed sediment & $\begin{array}{l}\text { Mixed sediment } \\
\text { (Mud } 95-10 \% \text {; Sand }<90 \% \text {; Gravel }>=5 \% \text { ) }\end{array}$ \\
\hline $\begin{array}{l}\text { (gravelly) Mud - (g)M } \\
\text { Mud -M } \\
\text { (gravelly) sandy Mud - (g)sM } \\
\text { sandy Mud - sM } \\
\text { (gravelly) muddy Sand - (g)mS } \\
\text { muddy Sand - mS }\end{array}$ & $\begin{array}{l}\text { Mud (Mud > }=90 \% \text {; Sand }<10 \% \text {; Gravel }<5 \% \text { ) } \\
\text { sandy Mud (Mud 50-90\%; Sand 10-50\%; Gravel < 5\%) } \\
\text { muddy Sand (Mud 10-50\%; Sand 50-90\%; Gravel }<5 \% \text { ) }\end{array}$ & $\begin{array}{l}\text { Mud to muddy Sand } \\
\text { (Mud } 100-10 \% \text {; Sand }<90 \% \text {; Gravel }<5 \% \text { ) }\end{array}$ \\
\hline $\begin{array}{l}\text { (gravelly) Sand }-(\mathrm{g}) \mathrm{S} \\
\text { Sand }\end{array}$ & Sand (Mud $<10 \%$; Sand $>=90 \%$; Gravel $<5 \%)$ & Sand \\
\hline
\end{tabular}

Figure 3. The Folk sediment triangle and the hierarchy of Folk classification (15, 6 and 4 classes, plus an additional class "rock and boulders," indicated by the arrow) used in the EMODnet Geology project. 
Table 2. Seabed substrate attribute table with 14 columns describing the data.

\begin{tabular}{|c|c|}
\hline Field & Comment/Advise \\
\hline FID & $\begin{array}{c}\text { Feature Identification. An internally generated identification number for each } \\
\text { polygon. }\end{array}$ \\
\hline Shape & Polygon. Internally generated text. \\
\hline Code & $\begin{array}{l}\text { Two-letter country code and three digits (numbers) that identify each data } \\
\text { patch. The code should be the same as the code in the INDEX map. }\end{array}$ \\
\hline Grain_Size & Original grain size classification system (e.g., Folk, Wentworth, MNCR). \\
\hline (re)Classifi & $\begin{array}{l}\text { (Re)Classification. If the surface substrates have been reclassified, were they } \\
\text { reclassified on the basis of sample data or by expert judgement? }\end{array}$ \\
\hline Method & $\begin{array}{l}\text { Information if the substrate map is interpolated automatically from the surface } \\
\text { samples or if the existing substrate polygons have been reclassified? }\end{array}$ \\
\hline Sample_n & $\begin{array}{c}\text { Sample number. Approximate the minimum number of samples used per } \\
\text { original substrate category. }\end{array}$ \\
\hline O_substrat & Original substrate category. Name of the original substrate category. \\
\hline Relation & $\begin{array}{l}\text { Relationship code. Code describes the relationship between two classification } \\
\text { schemes (original versus reclassified) (adapted from [20]). }\end{array}$ \\
\hline FOLK_16cl & Substrate material based on the Folk classification with 16 classes. \\
\hline FOLK_7cl & Substrate material based on the Folk classification with 7 classes. \\
\hline FOLK_5cl & Substrate material based on the Folk classification with 5 classes. \\
\hline Comments & Free comments. \\
\hline References & References. \\
\hline SEAREGION & The sea region, represented by the data. \\
\hline COUNTRY & $\begin{array}{l}\text { The national exclusive economic zone (EEZ) area, where the data is located or } \\
\text { the country of origin of the dataset. }\end{array}$ \\
\hline DATA_HOLDER & Abbreviation of the organization/institute. \\
\hline CONTACT & E-mail address of the contact person. \\
\hline
\end{tabular}

\subsection{Generalisation}

The EMODnet Geology network has provided seabed substrate maps at $250 \mathrm{k}$ and $1 \mathrm{M}$ scales for meso-/medium and mega-/broad scale data use, respectively [21,22]. National or regional datasets that were more detailed, were generalised to the target scale. The generalisation procedure was implemented in an ArcGIS environment and adapted from a procedure proposed by [23]. The procedure utilised mainly the Generalisation toolset of ArcGIS's Spatial Analyst toolbox. During generalisation at $250 \mathrm{k}$ and $1 \mathrm{M}$ scales, all sediment polygons smaller than $0.25 \mathrm{~km}^{2}$ and $4 \mathrm{~km}^{2}$ were eliminated.

\subsection{Compilation}

The reclassified and generalized national maps were merged to form continuous seafloor maps for European maritime areas. Cross-border mismatches between national datasets were analysed and corrected where possible. Topological correction (i.e., fixing overlaps and false gaps between substrate polygons) was performed on the $250 \mathrm{k}$ data, but not on the $1 \mathrm{M}$ data, owing to time constraints associated with delivering the project outputs. Following compilation, seabed substrate maps were made available on the EMODnet Geology data portal in digital format.

The seabed substrate coverage was compared with sea region coverage to assess which percentage of regional seas has been mapped, and to better understand the extent of the gap areas. Data on sea regions was modified from the EMODnet regions, version 1, dataset provided by [24]. 
The modifications include additions of sea areas around the Faroe Islands and of Atlantic waters west of the Celtic Sea. Data were projected onto UTM zones 29 N, 34 N or 37 N for areal estimates.

\subsection{Confidence Assessment}

Assessment and visualisation of confidence are an essential part of producing maps. It is crucial that users of the data/maps understand the strengths and weaknesses of the data. Confidence assessment examines uncertainty in the input data, determines the robustness of the analytical process, and evaluates the quality of the mapped output. Importantly, it describes how reliable map/data are for a given purpose.

A simple confidence assessment was applied to characterise the information that underpins the geological interpretations. Thus, the mapped confidence reflects the amount of information from seabed samples and acoustic data for any surveyed area. This approach effectively identifies data gaps, corresponding to areas with no data or where geologists have relatively little or no confidence in their interpretations, having had to interpolate or extrapolate from areas for which data exist.

Specifically, the index map as described above was used to assign a confidence score (0-4) using the "three-step confidence method" (Figure 4, Table 3) developed by the Joint Nature Conservation Council in the UK [25] as summarised below.

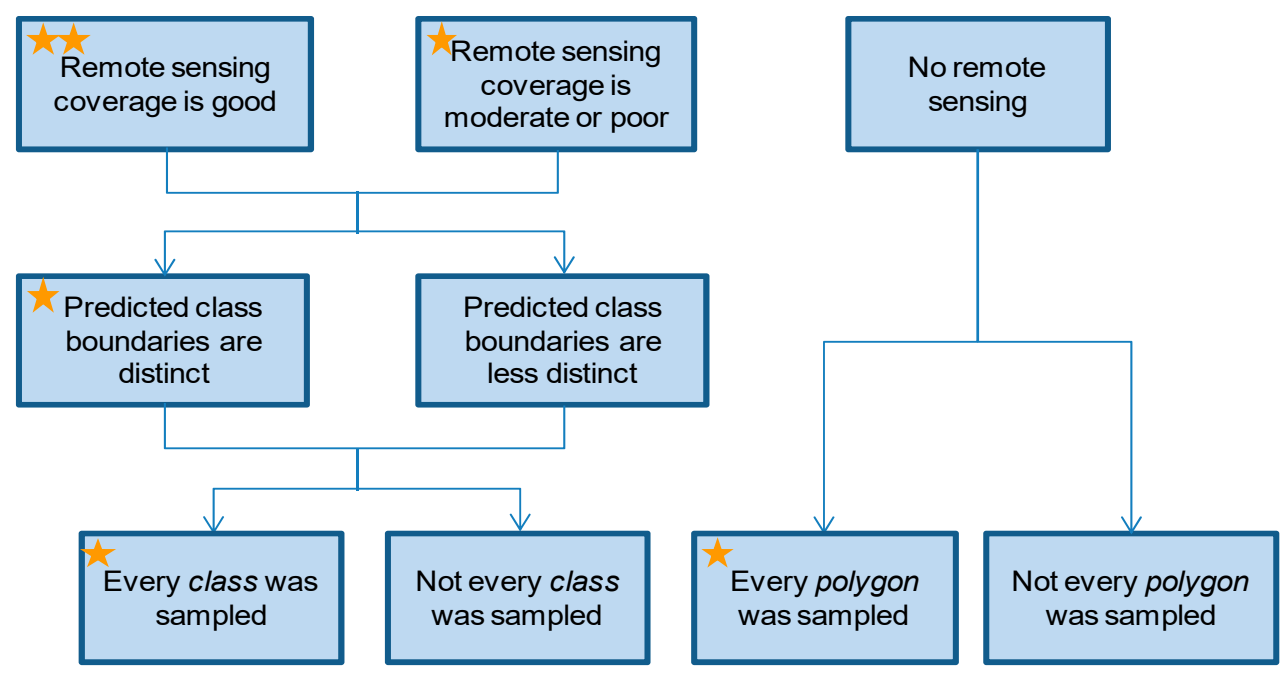

Figure 4. Confidence decision tree for EMODnet substrate mapping; the assessor starts at the top and follows the arrows.

Table 3. Different combinations of scores that are possible under the three-step confidence assessment method for EMODnet substrate maps.

\begin{tabular}{|c|c|c|c|}
\hline Remote Sensing Coverage & Distinctness of Class Boundaries & Amount of Sampling & Total Score \\
\hline$\star \star$ & $\star$ & $\star$ & 4 \\
\hline$\star \star \star$ & $\star$ & & \multirow{3}{*}{3} \\
\hline$\star \star \star$ & & $\star$ & \\
\hline$\star$ & $\star$ & $\star$ & \\
\hline$\star \star$ & & & \multirow{3}{*}{2} \\
\hline$\star$ & $\star$ & & \\
\hline$\star$ & & $\star$ & \\
\hline$\star$ & & & \multirow{2}{*}{1} \\
\hline & & $\star$ & \\
\hline & & & 0 \\
\hline
\end{tabular}




\section{Results}

\subsection{Index Data}

The index dataset identified more than 400 data patches from more than 50 organisations, altogether representing 31 countries. Inevitably, seabed substrate data originally had different scales/resolutions and grain size classifications (Figure 5) among others. A data table showing selected grain size ranges is included in the supplementary material (Table S1).

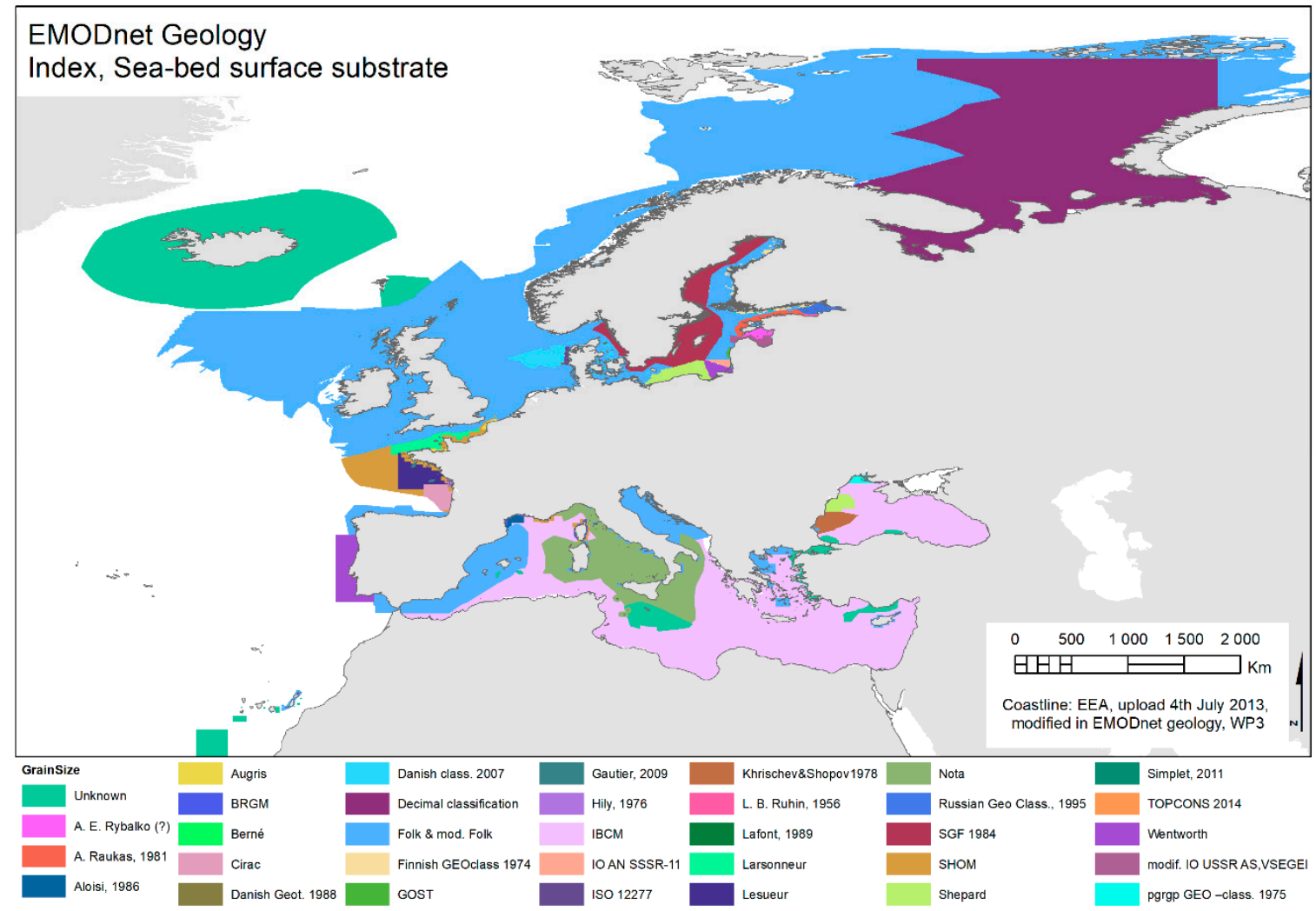

Figure 5. Different grain size classification systems used in seabed mapping by different European contributors participating in EMODnet-Geology. Data indicate more than 30 grain size classification schemes.

\subsection{Seabed Substrate Data Products}

All seabed substrate data are publicly available via EMODnet Geology portal (http:/ /www. emodnet-geology.eu/). Figures 6 and 7 show seabed substrate data products with a hierarchy of five classes (Folk 5) having the best spatial coverage. The $250 \mathrm{k}$ or more detailed seabed substrate data covers about $20 \%$ and $1 \mathrm{M}$ covers $65 \%$ of the European seas (Table 4 ). The $250 \mathrm{k}$ data (or more detailed) are most abundant for the Adriatic Sea, North Sea, Celtic Sea and wider Atlantic Ocean $(>70 \%$ ) (Table 4). For the Baltic Sea, $250 \mathrm{k}$ data coverage is 47\%. Areas for which no or little data are available, are mainly located further offshore in deep water. 




Figure 6. EMODnet Geology seabed surface substrate data at a scale of 1:250,000 (250 k) for the European seas, hierarchy of five Folk classes.

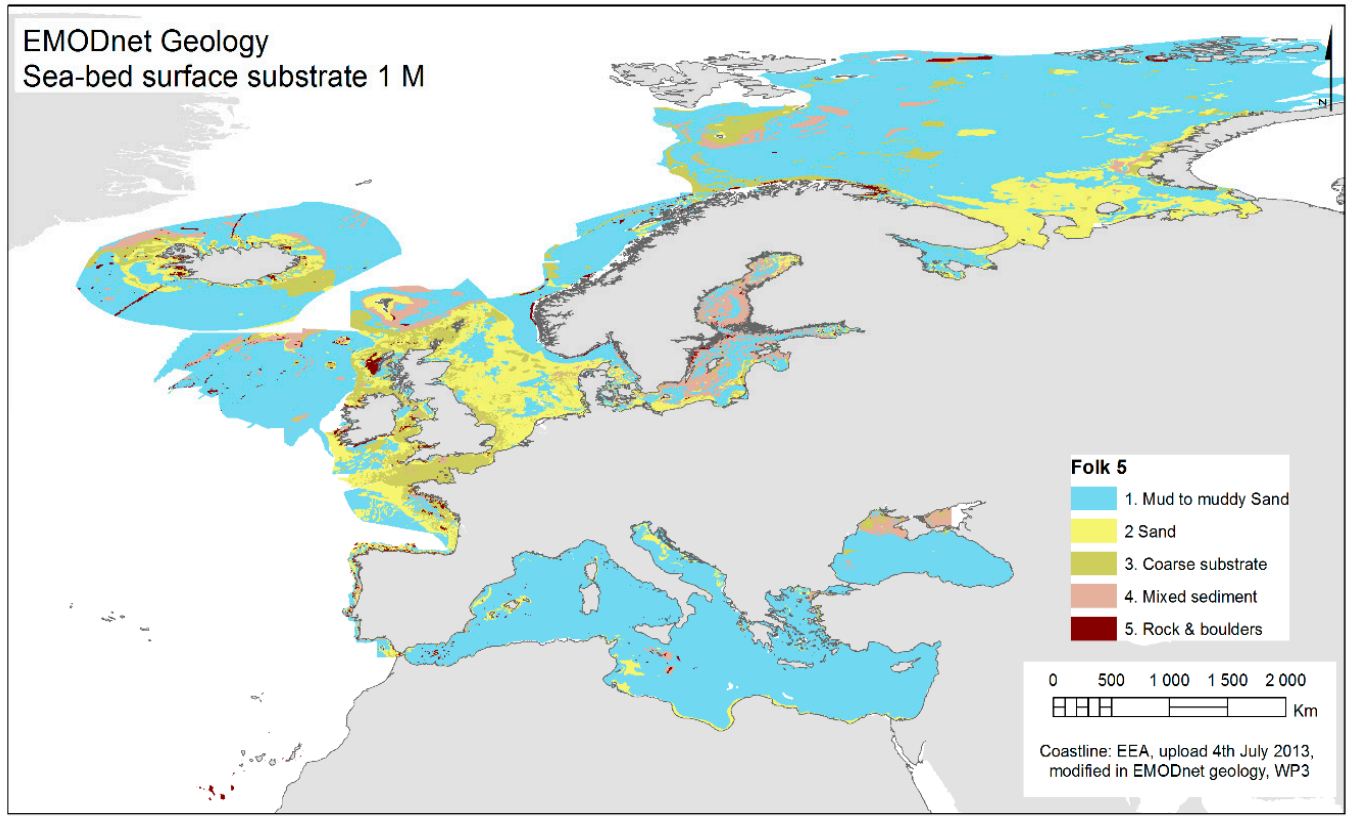

Figure 7. EMODnet Geology seabed surface substrate data at a scale of 1:1,000,000 (1 M) for the European seas, hierarchy of five Folk classes.

The $1 \mathrm{M}$ data product highlights that sea regions are different in their seabed substrate content (Figures 6-8). Mud to muddy sand is the dominant seabed substrate in the majority of Europe's sea basins. The North Sea and White Sea are predominantly sandy areas in comparison to the Baltic Sea with areas of mixed sediments (Figure 8). In some areas, such as in the Celtic Sea and North Sea, coarse substrates are relative common. At this broad scale, the bedrock and boulders class is uncommon in all sea basins. Even in the Baltic Sea it accounts for less than $5 \%$ of the seabed. 
Table 4. Approximate seabed substrate data coverage at different scales versus the extent of the sea region. Sea regions are shown in Figure 1.

\begin{tabular}{|c|c|c|c|c|c|c|}
\hline Sea Region & $\begin{array}{l}\text { Total Area } \\
\left(\mathbf{k m}^{2}\right)\end{array}$ & $\begin{array}{c}250 \mathrm{k} \\
\text { Coverage (\%) }\end{array}$ & $\begin{array}{l}250 \mathrm{k} \mathrm{No} \\
\text { Data (\%) }\end{array}$ & $\begin{array}{c}1 \text { M Coverage } \\
(\%)\end{array}$ & $\begin{array}{l}1 \mathrm{M} \mathrm{No} \\
\text { Data (\%) }\end{array}$ & $\begin{array}{l}\text { WGS 84, } \\
\text { UTM Zone }\end{array}$ \\
\hline Adriatic Sea & 140,400 & $91 \%$ & $9 \%$ & $98 \%$ & $2 \%$ & $34 \mathrm{~N}$ \\
\hline Aegean-Levantine Sea * & 767,200 & $6 \%$ & $94 \%$ & $99 \%$ & $1 \%$ & $34 \mathrm{~N}$ \\
\hline Baltic Sea & 394.200 & $47 \%$ & $53 \%$ & $98 \%$ & $2 \%$ & $34 \mathrm{~N}$ \\
\hline Barents Sea & $1,980,200$ & $6 \%$ & $94 \%$ & $78 \%$ & $22 \%$ & $37 \mathrm{~N}$ \\
\hline $\begin{array}{l}\text { Bay of Biscay and } \\
\text { Iberian Coast }\end{array}$ & 807,800 & $12 \%$ & $88 \%$ & $34 \%$ & $66 \%$ & $29 \mathrm{~N}$ \\
\hline Black Sea & 476,300 & $8 \%$ & $92 \%$ & $96 \%$ & $4 \%$ & $37 \mathrm{~N}$ \\
\hline Celtic Sea & 917,600 & $79 \%$ & $21 \%$ & $82 \%$ & $18 \%$ & $29 \mathrm{~N}$ \\
\hline Faeroe Islands EEZ & 267,400 & $0 \%$ & $100 \%$ & $39 \%$ & $61 \%$ & $29 \mathrm{~N}$ \\
\hline Greater North Sea & 679,300 & $81 \%$ & $19 \%$ & $96 \%$ & $4 \%$ & $29 \mathrm{~N}$ \\
\hline Iceland Sea & 761,700 & $0 \%$ & $100 \%$ & $100 \%$ & $0 \%$ & $29 \mathrm{~N}$ \\
\hline $\begin{array}{l}\text { Ionian Sea and Central } \\
\text { Mediterranean Sea * }\end{array}$ & 778,000 & $0 \%$ & $100 \%$ & $99 \%$ & $1 \%$ & $34 \mathrm{~N}$ \\
\hline Kara Sea & 113,500 & $0 \%$ & $100 \%$ & $0 \%$ & $100 \%$ & $37 \mathrm{~N}$ \\
\hline Macaronesia & $1,940,800$ & $0 \%$ & $100 \%$ & $0 \%$ & $100 \%$ & $29 \mathrm{~N}$ \\
\hline Norwegian Sea & 890,100 & $4 \%$ & $94 \%$ & $14 \%$ & $86 \%$ & $34 \mathrm{~N}$ \\
\hline $\begin{array}{l}\text { Western Mediterranean } \\
\text { Sea * }\end{array}$ & 885,100 & $9 \%$ & $91 \%$ & $99 \%$ & $1 \%$ & $29 \mathrm{~N}$ \\
\hline White Sea & 90,500 & $0 \%$ & $100 \%$ & $100 \%$ & $0 \%$ & $37 \mathrm{~N}$ \\
\hline Wider Atlantic & 405,300 & $77 \%$ & $23 \%$ & $77 \%$ & $23 \%$ & $29 \mathrm{~N}$ \\
\hline Grand Total & $12,296,900$ & $19 \%$ & $81 \%$ & $65 \%$ & $35 \%$ & $34 \mathrm{~N}$ \\
\hline
\end{tabular}

* African part included.



Figure 8. Distribution of seabed substrate types for different sea regions. "No data" gives the percentage of data gaps for a region. 


\subsection{Confidence}

The final score from $0-4$, reflecting low to high confidence, varies significantly even across short distances (Figure 9). Combinations of methods providing the highest confidence have only been in use since the advent of full-coverage acoustic mapping (SSS, MBES). Many of the traditional geological maps made until the 1980s rely on seabed samples only. Although modern geological mapping uses a combination of acoustics and ground-truthing, providing extensive full coverage especially in deep water where MBES swaths are wide, most high-confidence maps are made for ecological or project-based purposes of generally limited areal extent. Typically, sample density and MBES coverage are highest in regions where human activities take place.

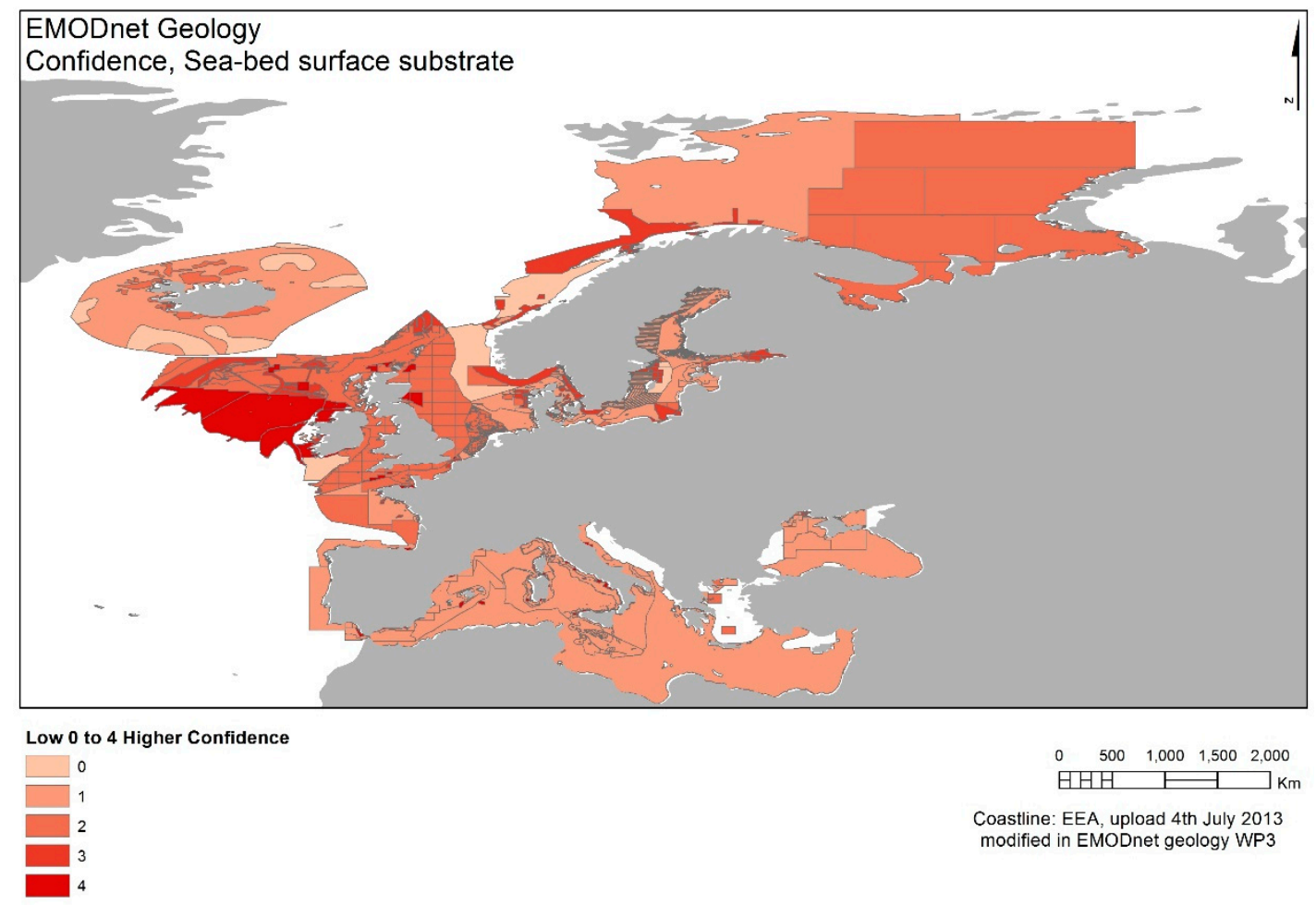

Figure 9. Confidence map of EMODnet Geology study area for seabed substrate map (1 M scale).

\section{Discussion}

\subsection{Harmonisation Process and Challenges}

Following up on the World Map of Seabed Sediment [26], EMODnet Geology has been collating all available seabed substrate maps for European seas to create single maps at different scales and Folk granularities. Each scale and granularity bring its own issues of harmonisation. As the original datasets have been produced by a variety of methods, final maps are multisource transboundary data. The variability of data is partly due to local/regional differences in the seabed environment and thus the methods used.

Attribute tables for the different map highlight the importance of metadata; even where a seabed substrate map looks continuous, the datasets behind may be highly variable. In visualising the quality of the data products, it is important to note that the confidence of the products is not uniform; thus, areas with similar characteristics are not always comparable. Both the metadata and the confidence information relating to a particular sea area are essential for end users and decision-makers to allow them to assess the limitations of the maps, and identify areas where further mapping or sampling is required. 
The national sediment classifications as well as the associated terminology vary between countries and have also changed through time. Owing to fundamental differences in data (e.g., grain-size ranges) it was not always possible to make one-to-one translation from a national substrate category into a Folk category. In some instances, the resulting class is a broad representation ignoring the overall substrate variability. In certain cases, the substrate is only an approximate estimate for the surface material from the uppermost $30 \mathrm{~cm}$ of the seabed sediment column. As noticed in the first EMODnet phase, substrate reclassification is especially ambiguous in the case of mixed sediment class, a somewhat "fuzzy" concept. The term mixed sediment has been interpreted differently by the partners during the harmonisation process. In the past, patchy seafloor, glacial clay and sediment with bimodal grain size distribution have all been identified as "mixed sediment" [27]. The data products presented here acknowledge mixed sediment on the basis of lithological class (gravel, sand, mud) and corresponding grain size only.

By necessity, the generalisation process requires deletion of information that may be crucial on a local or regional scale. In areas with high local seabed heterogeneity (i.e., geodiversity) broad scale data does not capture true diversity of the seafloor and some important features might not appear [28]. In the northern Baltic Sea, for example, large areas of seabed are marked by De Geer moraines that create a unique washboard-like seabed terrain with corresponding sediment and topographical variability [29]. These are not represented in the EMODnet maps. It does not mean; however, that these latter maps are wrong. Broad-scale data summarises the knowledge of general trends in a large area at the expense of detail to provide a contextual overview for transnational and pan-European science as well as decision-making.

One of the most time-consuming aspects of harmonisation was the topological correction of the data. Numerous mismatches between national datasets had to be rectified. It is a reminder of the fact that map alignment is a multidimensional exercise.

\subsection{European Seabed Substrate Data Coverage and Gaps}

One of the aims of the present work was to identify data gaps and deficiencies for different scales and granularities. Data gaps can be used to target future seabed surveys and mapping programmes. As the principal national organisations responsible for coastal and marine geological mapping, the EMODnet partnership profits directly from this expertise. Other beneficiaries include seabed-habitat mappers, spatial planners and engineering companies.

Overall coverage of the $250 \mathrm{k}$ data is generally poor $(19 \%)$. Only in some sea regions like in the North Sea $(81 \%)$ and the Celtic Sea $(79 \%)$, the majority of the sea region is covered at this scale. Data at scales of 1:100,000 (100 k) or finer is even rarer. Shallow coastal areas are particularly challenging. They commonly appear as unmapped patches forming what is known as the "white ribbon". The cost of surveying these areas is high, owing to the transient (e.g., shoals) and irregular (e.g., submerged rocks) nature of bathymetric features [29]. The lack of seabed substrate data for such areas is problematic especially because coastal areas are subject to extensive human activities (e.g., shipping, dredging, dumping, wind farm construction and aquaculture). There is an urgent need to provide high-resolution seabed data from these regions, regardless of anthropogenic pressures. The use of MBES data, especially backscatter, in marine geological mapping has greatly improved the resolution of seabed datasets [14,17]. In shallow coastal regions, it has been supplemented by airborne LiDAR providing high-resolution remote sensing data [29] that can be merged with MBES output.

The $1 \mathrm{M}$ data product covers $65 \%$ of the European maritime areas. Data gaps are located mainly in remote areas away from the coast (e.g., the outer boundaries of Macaronesia, Bay of Biscay and Iberian coast, Norwegian Sea and Barents Sea). In order to achieve full coverage at $1 \mathrm{M}$ scale, further seabed mapping surveys are ongoing. 


\subsection{Visualisation of European Seabed, Differences and Similarities between Sea Basins}

Seabed substrate maps provide a means to characterise the abiotic benthic environment. As substrates and their spatial distribution are a result of various abiotic and biotic processes, they also are a surrogate for marine habitats. Factors influencing sediment erosion, transport and accumulation and thus sediment distribution at the seafloor include grain size, current velocity, water depth (e.g., governing wave erosion), underwater topography, bedrock, distance from the coast (and river mouths), water masses, climate (e.g., governing ice cover, river discharge), biological productivity, benthic fauna and dissolution/preservation in the water column/seabed. The occurrence of hard substrates at the seabed, for example, may be indicative of strong currents at/close to the seabed. Soft laminated sediments may reflect a low-energy with potential oxygen deficiency at the bottom. It is important to keep in mind that erosion, transportation and accumulation of the sediments vary spatially and temporally and do not necessarily reflect present seabed processes. Even at a single location, the seabed substrate can be of different type and age, for example old glacial till is partially covered by modern mud. Bedrock outcrops may indicate sediment-starved seabed conditions or strong net erosion. Seabed dynamics leads to additional, temporal variability, especially where the spatial distribution of different substrate types at the seafloor is patchy. In this light, it is no surprise that secondary sediment properties (e.g., admixtures such as geochemical components) are unequally distributed at the seabed, displaying anthropogenic, glacial and other influences.

Seabed substrate maps of large sea areas are well-suited to visualising similarities as well as differences between the European sea basins (Figures 6-8). Mud to muddy sand is the dominant seabed substrate in the majority of sea basins, especially further from the coast, suggesting accumulation generally in deeper areas under low-energy conditions. In some basins such as the North Sea and the White Sea, sand is the dominant seabed surface substrate. Sand-rich areas are commonly close to a sediment source, such as a large river or a coastline marked by easily erodible sandstone. In formerly glaciated areas, the seabed may be dominated by glacigenic material, such as till and erratics or dropstones. The Baltic Sea is one of the European sea basins that was fully covered by an ice sheet during the last glaciation [30,31]. Here, a mixed substrate is typical. It includes till, and hard glacial clay, commonly with a thin layer of erosional sand on top. The seabed of the Baltic Sea basin is particularly heterogenous, especially in its northern parts [28] As outlined before, the broad scale EMODnet maps do not capture this local and regional seabed geodiversity. It can only be highlighted by detailed geological maps. When information on seabed substrate is analysed in conjunction with bathymetry and associated derivative products, underwater landscapes like drumlins and De Geer moraine fields can be revealed, with their corresponding sediments or rocks.

\subsection{Applications}

In general, seafloor substrate data can be used to better manage certain anthropogenic activities, such as underwater constructions, sand extraction and aquaculture, to assess habitat suitability, to develop guidelines or frameworks for monitoring environmental impact and to plan future geological surveys [28,32-35]. Information on seabed substrates is particularly valuable for marine habitat mapping and marine spatial planning, as seen in the application examples below.

\subsubsection{Seabed Substrates Characterising Seabed Ecosystems and Habitats}

Seabed substrate is one of the primary parameters in shaping the physical structure and function of benthic habitats, along with bottom topography, hydrography, wave exposure, biotic features and spatiotemporal variability $[36,37]$. In general, classification schemes for marine environments recognise hard, soft and mixed seabed substrates as being key factors controlling habitat type $[9,22,38,39]$. As it is known that relationships between environmental variables and organisms are dependent on scale [39-44], the EMODnet Geology maps can only be used for outlining the overall habitat distribution and suitability, showing how the seabed substrate strongly influences zoobenthic 
communities on regional and larger spatial scales $[37,45,46]$. Thus, it is possible to delineate areas dominated by coarse substrates, commonly inhabited by suspension feeders such as molluscs, and soft muddy basins inhabited by deposit feeders [38,45,47]. Sheltered sedimentation basins that may suffer from anoxia/hypoxia due to limited water exchange and are, therefore, poor in species [48,49], can also be outlined. Our maps do not lend themselves to identifying topographicallyand sedimentologically-complex seabed areas marked by relatively high species diversity $[50,51]$. Seabed substrate data shown here has been successfully used in the EMODnet Seabed Habitat work defining seabed habitats of the European seas. Our maps were key for the delineation of predominant broad-scale habitats that served as baseline for assessing good environmental status of marine waters in the framework of Europe's Marine Strategy Framework Directive.

\subsubsection{Seabed Substrates for Marine Spatial Planning and Research in the Gulf of Finland}

Information on seabed substrates is highly valuable for planning purposes and associated decision-making. In the Gulf of Finland, the easternmost part of the Baltic Sea, the Regional Council of Kymenlaakso has made Finland's first regional plan for the trade and sea area. The Ministry of the Environment has notarised this regional plan 26 November 2014 [52]. Marine geologists interacted with planners in order to evaluate which kind of environmental data were of direct practical relevance for spatial planning, which data were available and which much-needed data were lacking. EMODnet Geology seabed substrate data proved highly informative for the planners, especially in assessing "Valuable submarine geological features" and "Very important areas of geoand biodiversity". Intensive cooperation is essential to make scientific data on sea areas more easily available and understandable to maritime spatial (and other) planners and managers, and to improve the trust and interplay between science and planning officials.

EMODnet Geology seabed substrate data forms a solid base also for the new Gulf of Finland Assessment Report [53]. Information on sediment geochemistry and geological processes in particular has proven its value, showing the need to expand on the simple substrate characterisation used in EMODnet Geology today.

\subsection{Confidence}

Using and analysing multisource data inherently implies dealing with differences in data quality and uncertainty [54]. With EMODnet this is now visualised, thus targeted follow-up action can be taken. At this point, confidence has been assessed only in terms of easily quantifiable parameters. With 44 partner organisations involved in the creation of the final harmonised confidence layer, it was essential that the methodology was both objective and easy to follow. It uses widely available commercial software and data formats (ESRI ArcGIS).

The final confidence map provides a very quick and easy visualisation of the data that contributed to the final substrate map. It also allows the user to identify data gaps that could be filled only by extensive extrapolation, and highlights areas where collection of additional data would be beneficial. The scoring system; however, is heavily biased towards the availability of remote sensing data. If solely seabed samples are used, regardless of their number or density, confidence will be low even in areas marked by high uniformity. In using the density of data, the consistency of data, the scale of a map or the precision of a point's location and the age of data for the western Mediterranean, Garlan takes confidence assessment a step further. Nevertheless, as long as there is no differentiation in the quality of remote sensing and in the quality of acoustic seabed classification, confidence assessments will be flawed.

Importantly, there is not yet a scoring system incorporating the seabed dynamics of an area. At present, data are compiled regardless of their vintage; hence, datasets for different time periods are often combined to create a single map. In near-coastal areas with high sediment dynamics, seabed surface monitoring typically shows highly variable substrates through time, with seasonal, event- or 
activity-related and unexplained patterns [55]. The present phase of EMODnet has focused on the static mapping of available data, but future efforts should account for this temporal behaviour.

\section{Conclusions}

Seabed substrate mapping is a key asset for the management of the seabed. It is a critical contribution to marine spatial planning and it provides baseline information when assessing the impact of anthropogenic activities. However, seabed substrate information is typically fragmented and mostly classified to local or national standards.

Translating original seabed substrate data into the EMODnet Geology substrate classification scheme according to Folk, the EMODnet Geology consortium produced seabed substrate data products on a scale of $250 \mathrm{k}$ and $1 \mathrm{M}$ for the European seas. Both of these maps show similarities as well as vast differences in substrate types across the sea basins. Data were compiled from and harmonised for more than 400 individual datasets, with $20 \%$ coverage at a scale of $250 \mathrm{k}$ and $65 \%$ coverage at a $1 \mathrm{M}$ million scale. A simple confidence assessment enables the identification of the main data gaps.

The harmonised transboundary seabed substrate maps are available publicly and are easily accessible to marine managers, marine spatial planners, industry, academia and the general public. In most broad-scale cases, they will be fit for purpose, though data gaps or level of data resolution may hamper their use for some regions. Data are scarcest for offshore and near-coastal areas where surveying is most expensive or difficult. Since these restrictions can now be derived from the product, guidance is provided on where more extensive seabed surveys should be conducted.

The next steps in EMODnet Geology's seabed substrate mapping are increasing the resolution to reveal and quantify local complexity in seabed structure and composition, incorporating seabed dynamics to show the likelihood of temporal change, and improving our confidence assessment by including the quality of acoustic and other remote-sensing methods. All three will contribute to the sustainable management of Europe's seabed resources.

Supplementary Materials: The following are available online at http://www.mdpi.com/2076-3263/9/2/84/s1, Table S1: The Grain size limits in different classification systems.

Author Contributions: Writing-original draft preparation, A.T.K. and A.M.K.; writing-review and editing, U.A., R.C, J.G., S.v.H., S.K. and V.V.L.; data analysis, A.M.K., U.A., R.C., S.G., J.G., S.v.H. and V.V.L.; visualization, S.K.; project coordination/resources, A.S.

Funding: This study is part of the EU-funded EMODnet Geology project (EASME/EMFF/20I6/1.3.1.2 - Lot 1/SI2.750862), and was partly funded by the SmartSea project of the Strategic Research Council of the Academy of Finland (grant no. 292 985).

Acknowledgments: Thanks to the ur-EMODnet Geology and EMODnet 2 Geology partners who provided the geological data. Especially we would like to thank following persons: Fatima Abrantes, Zyad Al-Hamdani, Kristine Asch, Julie Auerbach, Loredana Battaglini, Reidulv Bo, Susana Bolhão Muiños, Baiba Brikmane, Ieva Bukovska, Gabri Carrara, Albert Caruana, Ingemar Cato, Bogomir Celarc, Nataliia Cheshenko, Gunay Cifci, Constantin Costea, Ranko Crmaric, Jolanta Čyžienè, Mateusz Damrat, Aldona Damusyte, Silvana D'Angelo, Markus Diesing, Lyubomir Dimitrov, Viktor Doda, Paraskevi Drakopoulou, Delia Dumitras, Antra Eihenberga, Mustafa Ergun, Ögmundur Erlendsson, Andrea Fiorentino, Charles Galea, Leonora Gelumbauskite, Eleni Georgiou Morisseau, Julia Gimenez Moreno, Helen Glaves, Javier González, Algimantas Grigelis, Ola Hallberg, David Hardy, Árni Hjartarson, Bartal Højgaard, Duncan Hume, Nikolina Ilijanic, Gabriel Ion, Agnese Jansone, Wojciech Jeglinski, Maria Judge, Roma Kanopiene, Dorota Kaulbarsz, Lars Kint, Nilhan Kizildag, Bernt Kjellin, Regina Kramarska, Špela Kumeli, Nenad Leder, Ricardo León, Jørgen Leth, Marisa Loureiro, Nuno Lourenco, Jonathan Lowndes, Stefan Marincea, Sokol Marku, Charise McKeon, Teresa Medialdea Cela, Slobodan Miko, Vytautas Minkevicius, Alexander Mirko Müller, Lis Mortensen, Cherith Moses, Inara Nulle, Johan Nyberg, Heidi Olsen, Sergii Osharin, Fabien Paquet, Arben Pambuku, Diana Persa, Piotr Przezdziecki, Slobodan Radusinovic, Ivana Raznatovic, Daria Ryabchuk, Dimitris Sakellariou, Jonas Satkunas, Odd Harald Selboskar, Tatjana Shadrina, Laure Simplet, Viktor Snezhko, Luis Somoza, Sten Suuroja, Agnes Tellez-Arenas, Pedro Terrinha, Isabelle Thinon, Terje Thorsnes, Konstantina Tsoumparaki-Kraounaki, Szymon Uscinowicz, Henry Vallius, Rokitskyi Valerii, Tamara Vandeven, Koen Verbruggen, Skuli Vikingsson, Annemiek Vink, Aspasia Zalachori, Irene Zananiri, Alexandra Zavitsanou, Manfred Zeiler, Vladimir Zhamoida and Zomenia Zomeni. We also thank two anonymous reviewers for comments that helped improve the manuscript.

Conflicts of Interest: The authors declare no conflicts of interest. 


\section{References}

1. Halpern, B.S.; Walbridge, S.; Selkoe, K.A.; Kappeli, C.V.; Micheli, F.; D’Argosa, C.; Bruno, J.F.; Casey, K.S.; Ebert, C.; Fox, H.E.; et al. A global map of human impact on marine ecosystems. Science 2008, 319, $948-952$. [CrossRef]

2. Halpern, B.S.; Frazier, M.; Potapenko, J.; Casey, K.S.; Koenig, K.; Longo, C.; Lowndes, J.S.; Rockwood, R.C.; Selig, E.R.; Selkoe, K.A.; et al. Spatial and temporal changes in cumulative human impacts on the world's ocean. Nat. Commun. 2015, 6, 7615. [CrossRef]

3. Lotze, H.K.; Lenihan, H.S.; Bourque, B.J.; Bradbury, R.H.; Cooke, R.G.; Kay, M.C.; Kidwell, S.M.; Kirby, M.X.; Peterson, C.H.; Jackson, J.B.C. Depletion, degradation, and recovery potential of estuaries and coastal seas. Science 2006, 312, 1806-1809. [CrossRef]

4. Doney, S.C.; Ruckelshaus, M.; Duffy, J.E.; Barry, J.P.; Chan, F.; English, C.A.; Galindo, H.M.; Grebmeier, J.M.; Hollowed, A.B.; Knowlton, N.; et al. Climate Change Impacts on Marine Ecosystems. Annu. Rev. Mar. Sci. 2012, 4, 11-37. [CrossRef]

5. European Commission. Communication from the Commission to the European Parliament, the Council, the European Economic and Social Committee and the Committee of the Regions. Innovation in the Blue Economy: Realising the Potential of our Seas and Oceans for Jobs and Growth. Brussels, 13.5.2014. COM 254. 2014. Available online: http:/ / eur-lex.europa.eu/legal-content/EN/TXT/PDF/?uri=COM:2014:254: REV1\&from=EN (accessed on 11 February 2017).

6. Zaucha, J. Sea basin maritime spatial planning: A case study of the Baltic Sea region and Poland. Mar. Policy 2014, 50, 34-45. [CrossRef]

7. European Parliament. Directive 2008/56/EC of the European Parliament and of the Council of 17 June 2008 Establishing a Framework for Community Action in the Field of Marine Environmental Policy (Marine Strategy Framework). 2008. Available online: http://eur-lex.europa.eu/legal-content/EN/TXT/?uri= CELEX\%3A32008L0056 (accessed on 11 February 2017).

8. European Parliament. Directive 2014/89/EC of the European Parliament and of the Council of 28 August 2014 Establishing a Framework for Maritime Spatial Planning (EU Maritime Spatial Planning Directive). 2014. Available online: https: / / eur-lex.europa.eu/legal-content/EN/TXT/HTML/?uri=CELEX:32014L0089\& from=ES. (accessed on 22 February 2019).

9. Davies, C.E.; Moss, D.; Hill, M.O. The EUNIS Habitat Classification Revised 2004; European Environment Agency: Dorset, UK, 2004.

10. Puttonen, I.; Mattila, J.; Jonsson, P.; Karlsson, O.M.; Kohonen, T.; Kotilainen, A.; Lukkari, K.; Malmaeus, J.M.; Rydin, E. Distribution and estimated release of sediment phosphorus in the northern Baltic Sea archipelagos. Estuar. Coast. Shelf Sci. 2014, 145, 9-21. [CrossRef]

11. Stevenson, A. The European marine observation and data network-geological data. Baltica 2012, 25, 87-90, Vilnius. ISSN 0067-3064. [CrossRef]

12. European Environmental Agency. EEA Coastline for Analysis. 2013. Available online: http://www.eea. europa.eu/data-and-maps/data/eea-coastline-for-analysis (accessed on 12 February 2013).

13. Foster-Smith, B.; Coltman, N.; Fitzpatrick, F. How good is my map? The MESH approach to confidence assessment. In MESH Guide: What Is Habitat Mapping? Foster-Smith, B., Connor, D., Davies, J., Eds.; Last Saved: 22/08/2007; Available online: http://www.emodnet-seabedhabitats.eu/default.aspx?page= 1900. (accessed on 12 February 2017).

14. Hughes Clarke, J.E.; Mayer, L.A.; Wells, D.E. Shallow-water imaging multibeam sonars: A new tool for investigating seafloor processes in the coastal zone and on the continental shelf. Mar. Geophys. Res. 1996, 18, 607-629. [CrossRef]

15. Coggan, R.; Populus, J.; White, J.; Sheehan, K.; Fitzpatrick, F.; Piel, S. (Eds.) Review of Standards and Protocols for Seabed Habitat Mapping. MESH. 2007. Available online: http:/ / www.emodnet-seabedhabitats.eu/default. aspx?page=1442 (accessed on 1 November 2016).

16. Van Lancker, V.; van Heteren, S.; Leth, J.; Kupschus, S.; Coggan, R.; Mason, C.; Monteys, X.; Scott, G.; Hardy, D.; Glaves, H. Geo-Seas, Pan-European Infrastructure for Management of Marine and Ocean Geological and Geophysical Data. Deliverable 10.5: Standards for Seabed Habitat Mapping (Part A: Sediment). Standardisation and Harmonisation in Seabed Habitat Mapping: Role and Added Value of Geological Data and Information. Part A: Sediment Characterisation. 2013. Available online: http: / / www.geo-seas.eu/content/content.asp?menu=0380000_000000 (accessed on 14 January 2019). 
17. Jakobsson, M.; Gyllencreutz, R.; Mayer, L.A.; Dowdeswell, J.A.; Canals, M.; Todd, B.J.; Dowdeswell, E.K.; Hogan, K.A.; Larter, R.D. Mapping submarine glacial landforms using acoustic methods. Geol. Soc. Lond. Mem. 2016, 46, 17-40. [CrossRef]

18. Folk, R.L. The distinction between grain size and mineral composition in sedimentary rock nomenclature. J. Geology 1954, 62, 344-359. [CrossRef]

19. Al-Hamdani, Z.K.; Reker, J.; Leth, J.O.; Reijonen, A.; Kotilainen, A.T.; Dinesen, G.E. Development of marine landscape maps for the Baltic Sea and the Kattegat using geophysical and hydrographical para meters. Geolo. Surv. Den. Greenl. Bull. 2007, 13, 61-64.

20. Coltman, N.; Golding, N.; Verling, E. Developing a broad-scale predictive EUNIS habitat map for the MESH study area. In MESH Guide to Marine Habitat Mapping; Joint Nature Conservation: Peterborough, UK, 2008.

21. Greene, H.G.; Yoklavich, M.M.; Starr, R.M.; O'Connell, V.M.; Wakefield, W.W.; Sullivan, D.E. A classification scheme for deep seafloor habitats. Ocenaologica Acta 1999, 22, 663-678. [CrossRef]

22. Greene, H.G.; Bizzarro, J.J.; O'Connell, V.M.; Brylinsky, C.K. Construction of digital potential marine benthic habitat maps using a coded classification scheme and its applications. Map. Seafloor Habitat Charact.: Geolo. Assoc. Can. Spec. P. 2007, 47, 141-155.

23. Hyvönen, E.; Jakonen, M.; Kupila, J.; Lerrsi, J.; Leskinen, J.; Liwata, P.; Nevalainen, R.; Putkinen, S.; Virkki, H. Maaperän yleiskartan tulkinta- ja kartoitusprosessi. Maaperän yleiskartoitus -hankkeen sisäinen raportti (in Finnish); Väänänen, T., Ed.; Report; Geological Survey of Finland: Espoo, Finland, 2007; p. 17.

24. VLIZ. IHO Sea Areas. 2014. Available online: http:/ / www.marineregions.org/ (accessed on 27 March 2017).

25. Lillis, H. A Three-Step Confidence Assessment Framework for Classified Seabed Maps; JNCC Report No. 591; JNCC: Peterborough, UK, 2016.

26. Garlan, T.; Gabelotaud, I.; Lucas, S.; Marchès, E. A World Map of Seabed Sediment Based on 50 Years of Knowledge. In Proceedings of the 20th International Research Conference, New York, NY, USA, 3-4 June 2018; 20 (6) Part, I.

27. Stevenson, A.; Kotilainen, A.; Kaskela, A.; Alanen, U.; Asch, K.; Schubert, C.; van Heteren, S.; van de Ven, T.; Thorsnes, T.; Verbruggen, K.; et al. EMODnet Geology Project Draft Final Report. Preparatory Actions for a European Marine Observation and Data Network; Lot No 2-Geological data. 40 pages; EMODnet Geology: Edinburgh, UK, 2011.

28. Kaskela, A.M.; Kotilainen, A.T. Seabed geodiversity in a glaciated shelf area, the Baltic Sea. Geomorphology 2017, 295, 419-435. [CrossRef]

29. Kotilainen, A.T.; Kaskela, A.M. Comparison of airborne LiDAR and shipboard acoustic data in complex shallow water environments: Filling in the white ribbon zone. Mar. Geol. 2017, 385, 250-259. [CrossRef]

30. Svendsen, J.I.; Alexanderson, H.; Astakhov, V.I.; Demidov, I.; Dowdeswell, J.A.; Funder, S.; Gataullin, V.; Henriksen, M.; Hjort, C.; Houmark-Nielsen, M.; et al. Late quaternary ice sheet history of northern Eurasia. In: Quaternary Environments of the Eurasian North (QUEEN). Quat. Sci. Rev. 2004, 23, 1229-1271. [CrossRef]

31. Stroeven, A.P.; Hättestrand, C.; Kleman, J.; Heyman, J.; Fabel, D.; Fredin, O.; Goodfellow, B.W.; Harbor, J.M.; Jansen, J.D.; Olsen, L.; et al. Deglaciation of Fennoscandia. Quat. Sci. Rev. 2016, 147, 91-121. [CrossRef]

32. Inger, R.; Attrill, M.J.; Bearhop, S.; Broderick, A.C.; James Grecian, W.; Hodgson, D.J.; Mills, C.; Sheehan, E.; Votier, S.C.; Witt, M.J.; et al. Marine renewable energy: Potential benefits to biodiversity? An urgent call for research. J. Appl. Ecol. 2009, 46, 1145-1153. [CrossRef]

33. Punt, M.J.; Groeneveld, R.A.; van Ierland, E.C.; Stel, J.H. Spatial planning of offshore wind farms: A windfall to marine environmental protection? Ecol. Econ. 2009, 69, 93-103. [CrossRef]

34. Handley, S.J.; Willis, T.J.; Cole, R.G.; Bradley, A.; Cairney, D.J.; Brown, S.N.; Carter, M.E. The importance of benchmarking habitat structure and composition for understanding the extent of fishing impacts in soft sediment ecosystems. J. Sea Res. 2014, 86, 58-68. [CrossRef]

35. Uścinowicz, S.; Jegliński, W.; Miotk-Szpiganowicz, G.; Nowak, J.; Pączek, U.; Przezdziecki, P.; Szefler, K.; Poreba, G. Impact of sand extraction from the bottom of the southern Baltic Sea on the relief and sediments of the seabed. Oceanologia 2014, 56, 857-880. [CrossRef]

36. Connor, D.W.; Allen, J.H.; Golding, N.; Lieberknecht, L.M.; Northern, K.O.; Reker, J.B. The National Marine Habitat Classification for Britain and Ireland, Version 03.02 Copyright JNCC, Peterborough ISBN 186107546 4. 2003. Available online: http:/ / www.jncc.gov.uk/MarineHabitatClassification (accessed on 25 November 2012). 
37. Snickars, M.; Gullström, M.; Sundblad, G.; Bergström, U.; Downie, A.-L.; Lindegarth, M.; Mattila, J. Species-environment relationships and potential for distribution modelling in coastal waters. J. Sea Res. 2014, 85, 116-125. [CrossRef]

38. Beaman, R.J.; Harris, P.T. Geophysical variables as predictors of megabenthos assemblages from the northern Great Barrier Reef, Australia. Mapp. Seafloor Habitat Charact.: Geol. Assoc. Can. Spe. P. 2007, 47, 241-257.

39. Last, P.R.; Lyne, V.D.; Williams, A.; Davies, C.R.; Butler, A.J.; Yearsley, G.K. A Hierarchical framework for classifying seabed biodiversity with application to planning and managing Australia's marine biological resources. Biol. Conserv. 2010, 143, 1675-1686. [CrossRef]

40. Zajac, R.N.; Lewis, R.S.; Poppe, L.J.; Twichell, D.C.; Vozarik, J.; DiGiacomo-Cohen, M.L. Responses of infaunal populations to benthoscape structure and the potential importance of transition zones. Limnol. Oceanogr. 2003, 48, 829-842. [CrossRef]

41. Post, A.L. The application of physical surrogates to predict the distribution of marine benthic organisms. Ocean Coast. Manag. 2008, 51, 161-179.

42. Williams, A.; Althaus, F.; Dunstan, P.K.; Poore, G.C.B.; Bax, N.J.; Kloser, R.J.; McEnnulty, F.J. Scales of habitat heterogeneity and megabenthos biodiversity on an extensive Australian continental margin (100-1100 m depths). Mar. Ecol. 2010, 31, 222-236. [CrossRef]

43. Buhl-Mortensen, L.; Buhl Mortensen, P.; Dolan, M.F.J.; Dannheim, J.; Bellec, V.; Holte, B. Habitat complexity and bottom fauna composition at different scales on the continental shelf and slope of Northern Norway. Hydrobiologia 2012, 685, 191-219. [CrossRef]

44. Zajac, R.N.; Vozarik, J.M.; Gibbons, B.R. Spatial and Temporal Patterns in Macrofaunal Diversity Components Relative to Sea Floor Landscape Structure. PLoS ONE 2013, 8, e65823. [CrossRef]

45. Rousi, H.; Peltonen, H.; Mattila, J.; Bäck, S.; Bonsdorff, E. Impacts of physical environmental characteristics on the distribution of benthic fauna in the Northern Baltic Sea. Boreal Env. Res. 2011, 16, 521-533.

46. Weigel, B.; Andersson, H.C.; Meier, H.E.M.; Blenckner, T.; Snickars, M.; Bonsdorff, E. Long-term progression and drivers of coastal zoobenthos in a changing system. Mar. Ecol. Prog. Ser. 2015, 528, 141-159. [CrossRef]

47. Post, A.L.; Beaman, R.J.; O’Brien, P.E.; Eléaume, M.; Riddle, M.J. Community structure and benthic habitats across the George V. Shelf, East Antarctica: Trends through space and time. Deep-Sea Res. II 2011, 58, 105-118. [CrossRef]

48. Laine, A.O. Distribution of soft-bottom macrofauna in the deep open Baltic Sea in relation to environmental variability. Estuar. Coast. Shelf Sci. 2003, 57, 87-97. [CrossRef]

49. Laine, A.O.; Andersin, A.-B.; Leiniö, S.; Zuur, A.-F. Stratification-induced hypoxia as a structuring factor of macrozoobenthos in the open Gulf of Finland (Baltic Sea). J. Sea Res. 2007, 57, 65-77. [CrossRef]

50. Kaskela, A.M.; Rousi, H.; Ronkainen, M.; Orlova, M.; Babin, A.; Gogoberidze, G.; Kostamo, K.; Kotilainen, A.T.; Neevin, I.; Ryabchuk, D.; et al. Linkages between benthic assemblages and physical environmental factors: The role of geodiversity in Eastern Gulf of Finland ecosystems. Cont. Shelf Res. 2017, 142, 1-13. [CrossRef]

51. Wennberg, S.; Lindblad, C.; Albertsson, J.; Bergström, U.; Isæus, M.; Kilnäs, M.; Mattisson, A.; Sandman, A. Sammanställning och Analys av Kustnära Undervattenmiljö (SAKU); Stockholm, Naturvårdsverket Rapport nr. 5591; Naturvårdsverket: Stockholm, Sweden, 2006; p. 99.

52. Kymenlaakson Liitto. Kymenlaakson maakuntakaava. Kauppa- ja merialue. Kaavaselostus. (In Finnish). 2014. Available online: http://www.kymenlaakso.fi/images/Liitteet/MAAKUNTAKAAVA/ Maakuntakaavakartat_ja_selosteet/Kauppa_ja_meri_kaavaselostus.pdf (accessed on 27 March 2017).

53. Kaskela, A.; Kotilainen, A.; Korneev, O.; Ryabchuk, D.; Rybalko, A.; Suuroja, S.; Vallius, H. Geodiversity. In The Gulf of Finland Assessment; Raateoja, M., Setälä, O., Eds.; Reports of the Finnish Environment Institute; Finnish Environment Institute: Helsinki, Finland, 2016; pp. 62-64.

54. Lecours, V.; Dolan, M.F.; Micallef, A.; Lucieer, V. A review of marine geomorphometry, the quantitative study of the seafloor. Hydrol. Earth Syst. Sci. 2016, 20, 3207-3244. [CrossRef]

55. Montreale Gavazzi, G.; Roche, M.; Degrendele, K.; Lurton, X.; Terseleer, N.; Baeye, M.; Francken, F.; van Lancker, V. Insights into the short-term tidal variability of multibeam backscatter from field experiments on different seafloor types. Geosciences 2019, 1, 34. [CrossRef]

(C) 2019 by the authors. Licensee MDPI, Basel, Switzerland. This article is an open access article distributed under the terms and conditions of the Creative Commons Attribution (CC BY) license (http://creativecommons.org/licenses/by/4.0/). 